\title{
Perceptions of Teacher Educators Regarding ICT Implementation in Israeli Colleges of Education
}

\author{
Orit Avidov Ungar \\ Achva Academic College, \\ and Open University \\ Israel \\ oritav65@gmail.com
}

\author{
Alona Forkosh Baruch \\ Tel-Aviv University, and \\ Levinsky College of Education \\ Israel
}

alonabar@post.tau.ac.il

\begin{abstract}
ICT (Information and Communication Technologies) in teacher education poses new challenges to faculty and students. This study was carried out to examine factors facilitating and hindering ICT implementation in teacher education institutes in Israel. Findings from our study, administered at two points in time, revealed that providing technological-pedagogical support to teacher educators and their perceptions and beliefs regarding ICT usage were consistent with being either facilitating or hindering factors in the integration process in colleges of education. Professional development of teacher educators in ICT skills and guidance in applying advanced technologies are additional facilitating factors. Resources, mainly time and infrastructure, were mostly a hindering factor with adverse influence on ICT integration. Three levels of successful ICT integration indicated successful implementation: teacher educators' level, students in their practice, and the organization level in terms of policy.
\end{abstract}

Keywords: teacher educators, ICT Implementation, facilitating factors, hindering factors, colleges of education

\section{Introduction}

Teacher training in Israel and worldwide has undergone major change in the last few decades, in an attempt to increase its professional standards and prestige - a priority in many countries; as a result there is a growing trend to recruit better preservice candidates (Darling-Hammond, 2006; Mumtaz, 2000; Toledo, 2005). The education system, including teacher education programs, is required to improve itself by becoming more relevant for the information era, by adopting techno-

(CC BY-NC 4.0) This article is licensed to you under a Creative Commons AttributionNonCommercial 4.0 International License. When you copy and redistribute this paper in full or in part, you need to provide proper attribution to it to ensure that others can later locate this work (and to ensure that others do not accuse you of plagiarism). You may (and we encourage you to) adapt, remix, transform, and build upon the material for any non-commercial purposes. This license does not permit you to use this material for commercial purposes. logical innovation. This may enable better reaction to global as well as local economic and social changes, in an attempt to raise students' achievements (UNESCO, 2009). Contemporary teacher training enforces colleges of education to adapt to these needs and to examine the means by which preservice teachers are exposed to ICT (Information and Communication Technologies) implementation processes during their training (Kay, 2006). In this process, teacher educators become a pillar in lead-

\section{Editor: Janice Whatley}

An earlier, shorter version of this paper was presented at the Chais conference 2016, in Raanana, Israel, and included in Y. Eshet-Alkalai, I. Blau, A. Caspi, N. Geri, Y. Kalman, \& V. Silber-Varod (Eds.), Proceedings of the 11th Chais Conference for the Study of Innovation and Learning Technologies 2016: Learning in the Technological Era. Raanana: The Open University of Israel. 
ing the expected change in training (Loughran, 2014; Thomas, Herring, Redmond, \& Smaldino, 2013). Lecturers and pedagogical advisors, comprising the teacher educating faculty, are expected to serve as models for preservice teachers in leading change in education and in reaching the highest standards (Loughran, 2014; Thomas et al., 2013); these standards apply to ICT implementation processes as a lever for developing innovation and entrepreneurship in education, among other educational criteria (Ertmer \& Ottenbreit-Leftwich, 2010; Pope, Hare \& Howard, 2005). Teacher educators may have critical influence on knowledge, skills, beliefs, and perceptions of preservice teachers, which may in turn have bearing on their craft as teachers (Koster, Brekelmans, korthagen \& Wubbels, 2005).

In the Israeli education system, as a result of global trends as well as local initiatives, a reform has been declared for implementing ICT in schools as part of a national initiative to adapt the education system to 21 st century requirements in terms of skills, knowledge, and competencies. In 2012 this initiative was broadened to include colleges of education by publishing a call to action by the Ministry of Education. The goals of this study were to examine factors aiding and preventing ICT implementation and what might be considered successful ICT implementation in teacher education, as perceived by teacher educators in colleges of education, and how these perceptions change over the timespan of the computerization initiative.

\section{Literature}

\section{ICT Implementation in the Education System}

One of the explanations of the notion that change is not implemented successfully in the culture of an organization is that "blocking forces" create a barrier in leading reforms and implementing change (Lewin, 1951). These obstructions that block technology diffusion in the education system focus on two major aspects: organizational-management factors that reflect the need for pedagogical and technological adaptations required for ICT implementation, and factors that reflect personal aspects, e.g., teachers' perceptions and beliefs regarding ICT implementation in their own teaching (Hultman, 1995; Sung \& Gibson, 2015; Teo, 2011). Also, there is a vague definition of what would be considered success in ICT implementation in education, causing tension and questions regarding the optimal implementation processes altogether (Kaniuka, 2012). Promoting as well as obstructing forces are influential on the ability to create processes of change and innovation within the education system (Cook, Holley, \& Andrew, 2007; Liu, 2011), as this is an ongoing and lengthy process (Kotter \& Cohen, 2012). Some studies define a 5-year period for implementing technology in an organization (Cummings \& Worley, 2015). This time span is vital for creating a process of change, in which the organization is exposed to an innovation and to its implementation process, then a diffusion process is carried out, in which novelties are disseminated and diffused into the organization. The organization in turn adopts new traits and categories among its members (Rogers, 1995). These are all necessary for the success of the implementation process and influence, in turn, the facilitating and hindering factors of change, as well as the organization's members' perceptions regarding this change (Surry, Ensminger, \& Jones, 2002).

\section{Teacher Educators' Role in ICT Implementation in Colleges of Education}

Teacher educators have a fundamental role in training preservice teachers for teaching in the information era, in utilizing ICT effectively, and in awareness of the facilitating and hindering factors related to this process (Drent \& Meelissen, 2008; Gomez, Sherin, Griesdorn, \& Finn, 2008). Teacher educators may serve as meaningful role models for ICT-based teaching; by doing this, they are able to design teaching patterns of preservice teachers and better prepare them for their future profession (Brzycki \& Dudt, 2005; Pope et al., 2005). Exposing these preservice teachers 
to novel pedagogical modes of teaching and learning, and experiencing them first-hand in terms of the added value of ICT for teaching and learning, may enhance their ability to implement these patterns in class (Goldstein et al., 2011, 2012). Teacher educators can influence knowledge, skills, and professional capabilities of their students, as well as their beliefs, attitudes and perceptions (Koster et al., 2005). Teachers attaining "digital wisdom" should be technologically independent, acquire technological-pedagogical knowledge, base their application of ICT on practical experience, and combine technology in education wisely (Siemens \& Tittenberger, 2009); the same is applicable to teacher educators (Krumsvik, 2014).

Educational reforms are popular among policymakers and are relatively frequent in the current era of change and innovation. This creates an identity crisis among teachers, which in turn influences their sense of self-efficacy, their satisfaction, and their commitment to the teaching profession (Day, Elliot, \& Kington, 2005). The larger the gap between teachers' perceptions, beliefs, and personal attitudes and the systemic perceptions regarding the meaning of being a professional teacher (a result of changes in the curricula as well as the educational milieu in general), the greater the friction that creates tension within the components of teachers' as well as preservice teachers' professional identity (Goktas, Yildirim, \& Yildirim, 2009; Merseth, Sommer, \& Dickstein, 2008). There is great importance to ensuring a dialog between change and new curricula (reflecting new policy) and teachers' professional perceptions developing within teacher education programs. Teacher educators have a major role in this dialog (Chong, Low, \& Goh, 2011; Lamote \& Engels, 2010).

\section{The Israeli National Program for the Computerization of Academic Colleges of Education}

Since Glister's (1997) original definition that "digital literacy is about mastering ideas not keystrokes," which paved the shift from traditional basic technical skills training, there has been a plethora of proposed models and frameworks for digital literacy/literacies, changing and adapting as new types of technology, media, and information sources arise, whilst also trying to anticipate future employment trends (All Aboard - Digital Skills in Higher Education, 2015, p. 18). Accordingly, the ministry of education in Israel in the past four years, starting in 2012, initiated a reform titled "The National Program for Adapting Education to the 21st Century, or in its more popular title, "The Israeli national ICT program". The program promotes ICT implementation in schools country-wide, thereby promoting higher order thinking skills, creativity, collaborative skills and additional skills needed for 21 st century citizens (Mioduser, Nachmias, \& Forkosh-Baruch, 2008). The new literacies serve as a basis for studies worldwide on ICT implementation in education and are also used for systemic studies on a national level as well, the in K12 (Kindergarten to 12 grade) system as well as in teacher training. The Israeli education system has based its computerization programs on such models. The development of Information and Communication Technologies (ICT) and the rapid growth of the Internet fundamentally influenced teacher preservice training in Israel as well. The Israeli Computerization Program has evolved from instrumental use of ICT in teaching to a genuine shift in pedagogical paradigms, massively influencing teaching and learning (Mandinach, 2005).

\section{National Computerization Program - Stage 1}

The National Computerization Program had begun its course as far back as 1994, running until the year 1998, following a National Report (Harari 1992; Ministry of Education Israel [MOE], 2003). The main purpose of this initial stage was to supply schools with infrastructure, as well as to train teachers in basic ICT implementation. In this stage, teacher education colleges training pre-service teachers were not included in the National Computerization Program. 


\section{National Computerization Program - Stage 2}

Schools in the education system participated in a 3-year stage of the National Computerization Program, beginning in 1998, which focused on implementing ICT in all subject matters. In this stage the policy emphasized the potential of ICT for teaching and learning, and the main goal of this stage was to empower and possibly implement novel pedagogy. Teacher education colleges training pre-service teachers were not included in this stage either.

\section{National Computerization Program - Stage 3}

As a result of a 3-year study focusing on the integration process of ICT in teacher education in Israel between the years 1993-2008, and in the light of theories of innovation and organizational change (e.g., Finley \& Hartman, 2004; Guri-Rosenblit, 2002; Hall \& Hord, 1987; Surry, Ensminger, \& Haab, 2005), teacher pre-service education was included in the third stage of this national initiative since 2011. The program for pre-service teachers was entitled: "The National Program for Adapting Teacher Education Colleges to the 21st Century", i.e., within 3 years all colleges were granted a sum of approximately $\$ 150,000$ each (altogether a sum of approximately $\$ 3,750,000$ for executing ICT-based educational initiatives for pre-service training, as well as for faculty training within each college. The initiative was funded by the Administration of Science and Technology as well as the Department for Teacher Training, both divisions in the Israeli Ministry of Education (MOE) (MOE Israel, 2011).

The Israeli Ministry of Education (Rimon, 2010) enforced this national program for adapting the academic colleges of education to 21 st century education as part of a holistic view of the education system in general and teacher professional development (TPD) in particular. The goal of this stage was to create a continuum of professional development, beginning with pre-service and creating ongoing in-service TPD. This is in line with the notion of lifelong learning (Lim, Chai, \& Churchill, 2011; Teo, 2010). According to this plan, colleges of education received funding for (a) upgrading their infrastructure, and (b) professional training of their faculty, dependent on the submission of institutional computerization programs for implementation of Information and Communication Technologies (ICT) in their training programs.

While the focus of the initial program was to install computers in classrooms and train teachers on a large-scale, the focus of the current program is manifold: (a) instilling 21 st century skills, (b) empowering teachers and teaching in schools, (c) adapting education to diverse students, (d) providing real-time feedback, (e) arousing interest among students, and (f) facilitating communication between teachers and other stakeholders within the education system. The main goal is to lead novel pedagogy in the education system, ICT having a major role in this initiative (MOE Israel, 2011). The Israeli Ministry of Education (MOE Israel, 2012) decided that colleges of education that are training future teachers will implement ICT in their teaching of teacher educators and will assist preservice teachers to implement ICT in their practice in schools during their training as future teachers in the education system.

A year after submitting the computerization programs, in 2012, nine colleges of education received the required funding on a competitive basis (according to the quality of the programs they submitted), and began to implement their three-year computerization plan. This process was accompanied by research, led by a research group including representatives from these colleges as well as from the Israeli MOE's Department for Teacher Training and Professional Development.

Respectively, the goal of this study is to examine what might be considered successful ICT implementation in teacher education, as perceived by teacher educators in colleges of education, and how these perceptions changed over the time span of the computerization program. In this study, we followed-up how these perceptions have changed within the boundaries of the program, in two time-periods about two years apart, i.e., at the beginning of the ICT implementation process 
and towards the end of the program. Research questions were, consequently, the following: What were the facilitating factors for ICT implementation in teacher training? What were the hindering factors for ICT implementation in teacher training? What would be considered effective ICT implementation in teacher training? Whether there are differences in these questions identified in two points in time: at the beginning of the initiative and towards the end of the 3 -year initiative?

\section{Method}

\section{Research Method}

This study is part of a large-scale collaborative study under the Mofet institute, a consortium of Israeli colleges of education which specializes in research, curriculum, and program development for teacher educators. The focus of the study as a whole is to gain insights regarding successes and challenges in the implementation process of the National Program for Adapting the Colleges of Education to the 21st Century. It was also aimed at supplying policymakers and stakeholders with information for creating a theoretical as well as practical framework for teacher training in the 21 st century in Israel.

In the current study, a qualitative research method was utilized, enabling exposure of unique meanings, characterization of processes and variables, and interpretation of the phenomena at the heart of this study. The study was conducted over two points in time, in which we compared the same items (Fraley \& Hudson, 2014; Kelly, Lesh, \& Baek, 2014), and teacher educators responded to an identical questionnaire in two points in time across a 3-year initiative: at its beginning and towards the end of the program (see: Hanus \& Fox, 2015).

Although the study was qualitative in nature, in order to compare differences over the period of the study a quantitative analysis of frequencies was conducted according to categories, with relation to the three research questions, e.g., facilitating factors, hindering factors, and measures of successful ICT implementation in colleges of education.

\section{Research Context and Population}

Respondents were teacher educators that serve as faculty members in academic colleges of education in Israel. Colleges that participated in the study included institutes that were awarded a budget based on a call to action by the Israeli MOE for implementing ICT in the training curricula. Hence, data was collected from 8 colleges of education (of 21 altogether), comprising some of the largest institutes for teacher training in Israel: 2 colleges from northern Israel, 3 from the center and 3 from the southern part of the country. These colleges were the first to implement ICT in a systemic manner.

The population included respondents of the questionnaire during two independent point in time, i.e., participants were not the same respondents in the year 2013 ( $\mathrm{N}=615$, which comprised 22.8\% of the teacher educators in these colleges) and in the year 2015 ( $\mathrm{N}=586$, which comprised $21.7 \%$ of the teacher educators in these colleges); hence we could not pair the responses and initially that was not our intention; rather, we aimed to identify general themes regarding the research questions we presented and possible differences in trends between the two point in time.

\section{Research Tools}

The tool used in this study was a questionnaire developed by a network of fellow-researchers from Israeli colleges of education (Goldstein et al., 2011, 2012). The questionnaire was developed for teacher educators and distributed in 8 colleges of education nationwide. It examined the perceptions and attitudes of teacher educators in colleges of education regarding ICT implementation in their teaching as well as the ways they use ICT and the intensity and scope of its usage. 
The questionnaire included a quantitative component and a qualitative component. In this article we refer to the qualitative component, comprising of three open-ended questions: (a) What encourages faculty to implement ICT in their teaching in the college? (b) What hinders ICT implementation of faculty in their teaching in education? (c) What would be considered a success in ICT implementation in the college? Data was collected in two points in time: the first in 2013 at the beginning of the national initiative, and the second in 2015, towards the end of the initiative.

The range of teacher educators who responded to the questionnaires in 2013 and 2015 was similar in terms of number of respondents as well as percent. Altogether, 615 teacher educators $(22.8 \%$ of total amount of teacher educators in these colleges) responded to the 2013 questionnaire, and 586 teacher educators $(21.7 \%$ of total amount of teacher educators in these colleges) responded to the 2015 questionnaire. The open-ended questionnaires reported in this study were addressed by only some of the participants. Table 1 details the scope of responses for each of the open-ended questions in each of the two administration points in time in terms of number of respondents and percent of the total respondents of the questionnaires.

Table 1: Percent of participants' responses to the open-ended questions of the total sample

\begin{tabular}{|c|c|c|c|c|c|}
\hline $\begin{array}{l}\text { Q } \\
\text { no. }\end{array}$ & Questions & $\begin{array}{l}\text { No. of re- } \\
\text { spondents }\end{array}$ & $\begin{array}{l}\text { \% of re- } \\
\text { spondent }\end{array}$ & $\begin{array}{l}\text { No. of re- } \\
\text { spondents }\end{array}$ & $\begin{array}{l}\text { \% of re- } \\
\text { spondents }\end{array}$ \\
\hline & & \multicolumn{2}{|c|}{$2013(\mathrm{~N}=615)$} & \multicolumn{2}{|c|}{$2015(\mathrm{~N}=586)$} \\
\hline Q 11 & $\begin{array}{l}\text { What would encourage you to im- } \\
\text { plement ICT in your teaching in } \\
\text { the college? }\end{array}$ & 383 & $62 \%$ & 306 & $52 \%$ \\
\hline Q 12 & $\begin{array}{l}\text { What would hinder your ICT im- } \\
\text { plementation in your teaching in } \\
\text { the college? }\end{array}$ & 433 & $74 \%$ & 294 & $50 \%$ \\
\hline Q 13 & $\begin{array}{l}\text { What would be considered a suc- } \\
\text { cess in effective ICT implementa- } \\
\text { tion in teaching in the college? }\end{array}$ & 360 & $58 \%$ & 226 & $39 \%$ \\
\hline
\end{tabular}

There were more responses to all open-ended questions in the first administration of the questionnaire in the year 2013. The lowest percent of responses was to the question regarding what would be considered successful ICT implementation in the college. This may have been a more complex notion compared to the first two questions referring to facilitating and hindering factors of ICT implementation in colleges of education, which may have been easier to address.

\section{Data Analysis}

Analysis of the open-ended responses included the following stages. (a) Responses were classified according to the three research questions: statements referring to facilitating factors of ICT implementation in the college of education, statements referring to hindering factors of ICT implementation in the college, and statements referring to successes in ICT implementation in the college. (b) Respondents' statements were classified according to themes or characteristics, e.g., lack of time, successful peer support. If a response included more than one characteristic, it was divided and assigned to more than one theme, e.g., "there is a need for teacher educators to collaborate and to learn together". (c) Similar segments of statements were collected and assigned to one major category. Similarly, an ensemble of categories was created, exhibiting the main themes found in the respondents statements, e.g., the two statements "to receive ICT tools" and "to influence teacher education" were assigned to the category "professional development". (d) The seg- 
ment-count within each category was according to types (vs. tokens). Two researchers examined the statements and assigned them (or their segments) to categories. Segments under dispute were discussed until a joint decision was reached regarding its classification. (e) Quantitative analysis of frequencies was conducted according to categories, with relation to the three research questions, e.g., facilitating factors, hindering factors, and measures of successful ICT implementation in colleges of education. This was of value for comparing responses from the two points in time at which the questionnaire was administered. Analysis was conducted for each of the time slots separately; results herewith will present a quantitative comparison of categories between responses in 2013 and 2015.

\section{Results}

Results of the study will be presented in the following 3 sub-sections, according to the three research questions: factors encouraging ICT implementation in colleges of education, factors hindering ICT implementation in these colleges, and perception of success in implementation in these colleges from the viewpoint of teacher educators. We include qualitative data in order to present the nature of the category, and quantitative data - to compare the two points in time; this is achieved by descriptive statistics that portray the strength of each category.

\section{Factors Encouraging the Implementation of ICT among Teacher Educators in Colleges of Education}

Altogether, 20 categories were found to be encouraging ICT implementation among teacher educators in colleges of education. When analyzing results from 2013 and 2015, additional meaningful categories were found in the later survey, as well as categories that were more salient. Technological-pedagogical support to teacher educators was found to be the most meaningful category in teacher educators' ICT implementation in their teaching, even more in 2105 when compared to 2013 (39.5\% and 31\% respectively). Three categories that were not mentioned in 2013 as encouraging factors, but were mentioned in the latter survey of 2015, were the need for demonstrating effective ICT implementation, adaptation of technology for systemic needs, and students' knowledge and motivation for implementing ICT in their teaching and learning.

Findings show that the importance of some categories that are considered as facilitators of ICT in teaching had dropped as perceived by teacher educators in the second survey in 2015 compared to the first survey in 2013. These include professional development, e.g., encompassing instruction, professional mentoring and exposure to workshops - all of which were considered more encouraging in the 2013 survey compared to the 2015 survey (24\% and $15.7 \%$ respectively). Similarly, adequate rewarding for teacher educators for ICT implementation in their teaching (17\% in 2013 vs. $10.5 \%$ in 2015$)$, availability and accessibility of technological equipment in the college $(15 \%$ in 2013 vs. $10.5 \%$ in 2015), as well as perceptions and beliefs of teacher educators regarding ICT implementation in teaching ( $19 \%$ in 2013 vs. $15.4 \%$ in 2015$)$ were all more frequently mentioned in the first survey. The three new categories mentioned in 2015 as facilitators of ICT implementation within colleges of education were time for adapting to change, modeling, and adaptation of technology to systemic requirements. Table 2 presents a comparison of all facilitating factors of ICT implementation in 2013 and in 2015, according to content analysis of teacher educators' responses, as well as some exemplary quotes. 
Table 2: distribution of responses regarding encouragements to implement ICT in teacher educators' teaching 2013 and 2015

\begin{tabular}{|c|c|c|c|c|c|}
\hline \multirow[b]{2}{*}{ No. } & \multirow[b]{2}{*}{ Categories } & \multicolumn{2}{|c|}{2013} & \multicolumn{2}{|c|}{2015} \\
\hline & & $\begin{array}{l}\text { no. of re- } \\
\text { sponses }\end{array}$ & \% of responses & $\begin{array}{l}\text { no. of re- } \\
\text { sponses }\end{array}$ & $\begin{array}{l}\text { \% of re- } \\
\text { sponses }\end{array}$ \\
\hline \multirow[t]{2}{*}{1} & $\begin{array}{l}\text { Technological-pedagogical } \\
\text { support to teacher educators }\end{array}$ & 123 & $\% 31$ & 121 & $\% 39.5$ \\
\hline & \multicolumn{5}{|c|}{$\begin{array}{l}\text { "We get workshops on implementing additional novel technological means, beyond the traditional } \\
\text { workshops for introducing usages of Moodle." }\end{array}$} \\
\hline \multirow[t]{2}{*}{2} & $\begin{array}{l}\text { ICT professional develop- } \\
\text { ment workshops, instruction } \\
\text { and ongoing professional } \\
\text { guidance }\end{array}$ & 93 & $\% 24$ & 48 & $\% 15.7$ \\
\hline & \multicolumn{5}{|c|}{$\begin{array}{l}\text { "The instructions published for using the various options in Moodle really help me. And when in } \\
\text { need, I use the technical help that the college offers." }\end{array}$} \\
\hline \multirow[t]{2}{*}{3} & ICT attitudes and beliefs & 72 & $\% 19$ & 47 & $\% 15.4$ \\
\hline & \multicolumn{5}{|c|}{ "I believe that this is the change needed in the college, we have a responsibility for training students." } \\
\hline \multirow[t]{2}{*}{4} & Offering incentives & 65 & $\% 17$ & 32 & $\% 10.5$ \\
\hline & \multicolumn{5}{|c|}{$\begin{array}{l}\text { "In the college we were greatly appreciated for our investment in the implementation of ICT. We } \\
\text { even received hours for it." }\end{array}$} \\
\hline 5 & $\begin{array}{l}\text { Accessibility and availability } \\
\text { of equipment for teacher edu- } \\
\text { cators and students }\end{array}$ & 59 & $\% 15$ & 32 & $\% 10.5$ \\
\hline 6 & Allocation of time & 38 & $\% 10$ & 32 & $\% 10.5$ \\
\hline 7 & $\begin{array}{l}\text { College physical conditions } \\
\text { and infrastructure }\end{array}$ & 25 & $\% 6.5$ & 31 & $\% 10$ \\
\hline 8 & $\begin{array}{l}\text { Supportive and mandatory } \\
\text { policy }\end{array}$ & 21 & $\% 5.5$ & 23 & $\% 7.5$ \\
\hline 9 & Students implementing ICT & 20 & $\% 5$ & 22 & $\% 7$ \\
\hline 10 & $\begin{array}{l}\text { Collaboration between teach- } \\
\text { er educators }\end{array}$ & 15 & $\% 4$ & 20 & $\% 6.5$ \\
\hline 11 & Promoting efficiency at work & 12 & $\% 3$ & 17 & $\% 5.6$ \\
\hline 12 & $\begin{array}{l}\text { Challenge, innovation, moti- } \\
\text { vation }\end{array}$ & 9 & $\% 2$ & 15 & $\% 4.9$ \\
\hline 13 & $\begin{array}{l}\text { Experience and practice in } \\
\text { ICT implementation in teach- } \\
\text { ing }\end{array}$ & 9 & $\% 2$ & 14 & $\% 4.6$ \\
\hline 14 & Don't know what encourages & 5 & $\% 1$ & 13 & $\% 4.3$ \\
\hline 15 & $\begin{array}{l}\text { Support and encouragement } \\
\text { of the head of department }\end{array}$ & 4 & $\% 1$ & 11 & $\% 3.6$ \\
\hline 16 & $\begin{array}{l}\text { Physical conditions and in- } \\
\text { frastructure in schools and } \\
\text { kindergartens }\end{array}$ & 3 & $\% 0.8$ & 7 & $\% 2.3$ \\
\hline 17 & Time to adapt to change & 2 & $\% 0.5$ & 3 & $\% 1$ \\
\hline 18 & Demonstration/modeling & 0 & $\% 0$ & 2 & $\% 6.5$ \\
\hline 19 & $\begin{array}{l}\text { Adapting technology to the } \\
\text { system }\end{array}$ & 0 & $\% 0$ & 2 & $\% 4.9$ \\
\hline 20 & $\begin{array}{l}\text { Students' knowledge and } \\
\text { motivation }\end{array}$ & 0 & $\% 0$ & 1 & $\% 4.6$ \\
\hline
\end{tabular}




\section{Factors Hindering the Implementation of ICT among Teacher Educators in Colleges of Education}

Analysis of data from the two surveys in 2013 and 2015 shows that almost all categories mentioned by teacher educators in 2013 as hindering ICT implementation were perceived more significant in 2015, as shown by their increased frequency of being mentioned. However, the two categories perceived as the most significant in hindering ICT implementation among teacher educators in their teaching were similarly important in both 2013 and 2015: i.e., time resources, technological infrastructure and rewarding; and ICT knowledge, skills and competencies of teacher educators. Additional factors hindering ICT implementation in teaching as perceived by teacher educators are infrastructure and technological aspects in the college, $(20 \%$ in 2013 and $15 \%$ in 2015), and beliefs and perceptions of teacher educators towards ICT (12\% in 2013 and $19 \%$ in 2015). College policy was mentioned to a lesser extent as a hindering category regarding ICT implementation (6\% in 2013 and 8\% in 2015). The two categories found in 2015 but not in 2013 were adaptation of ICT to system requirements and aspects related to the process itself. Factors hindering ICT implementation in teacher educators' teaching and a comparison between the two periods of survey administration (including participants' quotes) are presented in Table 3, as well as some exemplary quotes.

Table 3: distribution of responses regarding impediments to implementing ICT in teacher educators' teaching 2013 and 2015

\begin{tabular}{|c|c|c|c|c|c|}
\hline & & \multicolumn{2}{|c|}{2013} & \multicolumn{2}{|c|}{2015} \\
\hline No. & Categories & $\begin{array}{l}\text { no. of re- } \\
\text { sponses }\end{array}$ & $\begin{array}{l}\text { \% of re- } \\
\text { sponses }\end{array}$ & $\begin{array}{l}\text { no. of re- } \\
\text { sponses }\end{array}$ & $\begin{array}{l}\text { \% of respons- } \\
\text { es }\end{array}$ \\
\hline \multirow[t]{2}{*}{1} & $\begin{array}{l}\text { Resources, especially time } \\
\text { resources }\end{array}$ & 135 & $\% 30$ & 93 & $\% 31.6$ \\
\hline & \multicolumn{5}{|c|}{ "The enormous time investment required for preparing meaningful ICT-based lessons." } \\
\hline \multirow[t]{2}{*}{2} & $\begin{array}{l}\text { Knowledge, skills, instruc- } \\
\text { tion }\end{array}$ & 97 & $\% 21$ & 65 & $\% 22$ \\
\hline & \multicolumn{5}{|c|}{ "Lack of knowledge and lack of understanding of the possibilities before me." } \\
\hline \multirow[t]{2}{*}{3} & $\begin{array}{l}\text { Infrastructure and techno- } \\
\text { logical aspects }\end{array}$ & 68 & $\% 15$ & 58 & $\% 20$ \\
\hline & \multicolumn{5}{|c|}{ "Lack of classes for ICT-based instruction", "Shortage of laptops for students." } \\
\hline \multirow[t]{2}{*}{4} & $\begin{array}{l}\text { Perceptions and beliefs of } \\
\text { teacher educators regarding } \\
\text { ICT and its implementation }\end{array}$ & 55 & $\% 12$ & 56 & $\% 19$ \\
\hline & \multicolumn{5}{|c|}{$\begin{array}{l}\text { "Some of the teacher educators, and myself a bit as well... we don't really believe that you } \\
\text { can implement ICT in teaching in a way that changes instruction and makes it better." }\end{array}$} \\
\hline 5 & No hindering factors & 31 & $\% 7$ & 43 & $\% 15$ \\
\hline 6 & $\begin{array}{l}\text { Institute policy regarding } \\
\text { ICT implementation }\end{array}$ & 29 & $\% 6$ & 23 & $\% 8$ \\
\hline 7 & Adequate rewarding & 24 & $\% 5$ & 15 & $\% 5$ \\
\hline 8 & $\begin{array}{l}\text { Competencies and readi- } \\
\text { ness of students }\end{array}$ & 13 & $\% 3$ & 12 & $\% 4$ \\
\hline 9 & $\begin{array}{l}\text { Adapting technology sys- } \\
\text { temic needs }\end{array}$ & 0 & $\% 0$ & 10 & $\% 3$ \\
\hline 10 & $\begin{array}{l}\text { Aspects connected to the } \\
\text { process itself }\end{array}$ & 0 & $\% 0$ & 9 & $\% 3$ \\
\hline
\end{tabular}




\section{Perceived Indicators of Success in the Implementation of ICT among Teacher Educators in Colleges of Education}

When comparing the data of 2013 and 2015, results also show that with regards to success in implementing ICT, all categories mentioned in 2013 were perceived as more significant it 2015 , some exhibiting vast differences. One exceptional category was ICT implementation in academic courses, perceived as an equally central and significant measure for success in both surveys. Contrary to this, some categories were found as more frequent in perception of success in 2015 compared to 2013: students implementing ICT in their practice ( $29 \%$ in 2015 vs. $15 \%$ in 2013 ); resources, infrastructure and budgeting (27\% in 2015 vs. $10 \%$ in 2013); perceiving technological change as a means for achieving goals (23\% in 2015 vs. 9\% in 2013); investment vs. output tradeoff (17\% in 2015 vs. $9 \%$ in 2013); supportive college policy ( $16 \%$ in 2015 vs. $6 \%$ in 2013 ); and teacher educators' motivation (10\% in 2015 vs. $4 \%$ in 2013). ICT implementation in schools was perceived as marginal in both surveys.

The categories found among teacher educators based on their responses to the question of what would be considered success in ICT implementation in colleges of education, when comparing results from content analysis of responses in 2013 and 2015 are presented in Table 4, as well as some exemplary quotes.

Table 4: distribution of responses regarding what would be considered success in implementing ICT in teacher educators' teaching

\begin{tabular}{|c|c|c|c|c|c|}
\hline \multirow[b]{2}{*}{ No. } & \multirow[b]{2}{*}{ Categories } & \multicolumn{2}{|c|}{2013} & \multicolumn{2}{|c|}{2015} \\
\hline & & $\begin{array}{l}\text { no. of re- } \\
\text { sponses }\end{array}$ & $\begin{array}{l}\text { \% of re- } \\
\text { sponses }\end{array}$ & $\begin{array}{l}\text { no. of re- } \\
\text { sponses }\end{array}$ & $\begin{array}{l}\text { \% of re- } \\
\text { sponses }\end{array}$ \\
\hline \multirow[t]{2}{*}{1} & $\begin{array}{l}\text { Teacher educators imple- } \\
\text { menting ICT }\end{array}$ & 146 & $\% 38$ & 95 & $\% 40$ \\
\hline & \multicolumn{5}{|c|}{$\begin{array}{l}\text { "Success in ICT [implementation] is success in maximal utilization of technology for appli- } \\
\text { cation of various pedagogical ideas suitable for teaching goals of lecturers and for the content } \\
\text { they teach. Variation in teaching methods and teaching environments, including encourage- } \\
\text { ment of mobile learning, collaborative learning, distance learning, project based learning - } \\
\text { can all mark success in implementing ICT in the college." }\end{array}$} \\
\hline \multirow[t]{2}{*}{2} & $\begin{array}{l}\text { Students implementing ICT } \\
\text { in their practice }\end{array}$ & 55 & $\% 15$ & 64 & $\% 29$ \\
\hline & \multicolumn{5}{|c|}{ "The success is the moment graduate students begin to use ICT wisely and without fear." } \\
\hline \multirow[t]{2}{*}{3} & $\begin{array}{l}\text { Resources, budget, infra- } \\
\text { structure }\end{array}$ & 35 & $\% 10$ & 61 & $\% 27$ \\
\hline & \multicolumn{5}{|c|}{ "Making technology accessible for lecturers and students, availability of massive support." } \\
\hline \multirow[t]{2}{*}{4} & $\begin{array}{l}\text { Technological change as } \\
\text { means for achieving goals }\end{array}$ & 32 & $\% 9$ & 50 & $\% 23$ \\
\hline & \multicolumn{5}{|c|}{$\begin{array}{l}\text { "That lecturers will want to implement ICT out of their own choice and not as a necessity", } \\
\text { "A process that takes time, everyone joins the process in the place and measures suitable for } \\
\text { them". }\end{array}$} \\
\hline 5 & $\begin{array}{l}\text { Investment vs. output } \\
\text { tradeoff }\end{array}$ & 34 & $\% 9$ & 39 & $\% 17$ \\
\hline 6 & Supportive college policy & 21 & $\% 6$ & 37 & $\% 16$ \\
\hline 7 & Negative attitudes & 24 & $\% 6$ & 37 & $\% 16$ \\
\hline 8 & $\begin{array}{l}\text { Teacher educators' motiva- } \\
\text { tion }\end{array}$ & 15 & $\% 4$ & 22 & $\% 10$ \\
\hline 9 & $\begin{array}{l}\text { ICT implementation in } \\
\text { schools }\end{array}$ & 15 & $\% 4$ & 8 & $\% 4$ \\
\hline
\end{tabular}


Examination of teacher educators' responses to the question of what would be considered success in ICT implementation in colleges of education found 3 major measures: success measures related to students, those related to teacher educators, and those referring to the college organization and its policy. In the first survey in 2013, 377 statements were counted regarding measures of success in ICT implementation in colleges, while in 2015391 statements were counted. Table 5 details these statements according to the 3 levels.

Table 5: Quantification of measures of success according to 3 levels of ICT implementation: student, teacher educator and college level - a comparison between 2013 and 2015

\begin{tabular}{|l|c|c|c|c|}
\hline & \multicolumn{2}{|c|}{2013} & \multicolumn{2}{c|}{2015} \\
\hline Level & No. statements & $\%$ statements & No. statements & $\%$ statements \\
\hline Student level & 72 & $19 \%$ & 76 & $19 \%$ \\
\hline Teacher educator level & 249 & $66 \%$ & 228 & $58 \%$ \\
\hline $\begin{array}{l}\text { Organization level (col- } \\
\text { lege }\end{array}$ & 56 & $15 \%$ & 87 & $22 \%$ \\
\hline
\end{tabular}

It seems that the perceived importance of organizational factors increased with regards to measures of successful ICT implementation of ICT in colleges of education. Hence, while there are similarities between the two points in time regarding facilitating as well as hindering factors of ICT implementation in these colleges, there are differences and growing tendencies exhibited by the scopes of some of the major categories, indicating a trend and shift from technology per se to techno-pedagogical concerns.

\section{Discussion}

ICT implementation in education in general focuses on its usage as a means of empowering teaching and learning, thereby achieving educational goals successfully and more effectively; hence, teacher education (i.e., preparing preservice teachers for teaching in an ICT-saturated era) is more challenging nowadays than in the pre-digital era. Teacher educators, therefore, are expected and encouraged to use ICT for enhancing the learning process of their preservice students as well as their self-efficacy in utilizing ICT, thereby modelling best practices of ICT implementation in schools (Drent \& Meelissen, 2008; Scherer, Siddiq \& Teo, 2015). This is portrayed in our data, and one of the indicators of success that had grown from the year 2013 to 2015 was students implementing ICT in their practice. This coincides with the now model of teacher training in the Israeli education system that encourages a bidirectional training method: pre-service teachers being trained by mentor teachers, but also contributing to their knowledge and skills (Ministry of Education, 2015).

Being a teacher educator entails the notion of professional development; however, the emphasis nowadays is not only on how to become, but also how to learn as a teacher educator (Martin, 2015; Mckeon \& Harrison, 2011). Professional development of teacher educators and its systematic research is a result of the growing interest on what it means to professionally develop as a teacher educator (Loughran, 2014). Indeed, the meaning of success in terms of ICT implementation from teacher educators' point of view according to our study is its incorporation in academic courses, i.e., faculty see themselves as models for their students when teaching pre-service teachers, thereby promoting their confidence and understanding of the benefits of ICT for teaching (Teclehaimanot, Mentzer, \& Hickman, 2011). 
The Israeli Computerization Program in teacher education was a result of a top-down approach to change; however, teacher educators experienced this program and its implementation within the scope between professional development and professional learning for teachers (Hardy, 2010). Our study emphasizes the need to focus on these two major aspects in teacher educators' professional development: on one hand, learning about pedagogy and learning outcomes as a major driver for growth (Avalos, 2011), and on the other hand, perceiving technology as a fundamental component for achieving this goal in the information era. This combination of technological knowledge and pedagogical knowledge - technological-pedagogical support to teacher educators - was mentioned in our study as a major facilitating factor for ICT implementation in teacher training by teacher educators.

Among facilitating factors, the one mentioned excessively was technical support, as in several previous studies; a wide literature review supports this finding (Buabeng-Andoh, 2012). Moreover, all studies conducted since the systemic implementation of ICT in education in countries worldwide have shown the need for technical support as a prerequisite for successful pedagogical achievements as a result of utilizing ICT (Plomp, Anderson, Law, \& Quale, 2009). The three additional factors - modeling of efficient ICT implementation in teaching, adaptation of technology to systemic needs, and knowledge and motivation of students to implement ICT in teaching and learning processes - are all of greater importance in the second survey. Literature regarding technology transfer identifies sixteen variables affecting this process; a latest survey identifies furthermore four key factors in knowledge and technology transfer: communication, i.e., the ability of a medium to convey task-relevant information and media; distance, i.e., proximity of technology; equivocality, i.e., concreteness of knowledge and technology; and motivation, i.e., the incentives for technology transfer activities (Sung \& Gibson, 2015). Hence, there is need for a systemic viewpoint of teacher education for technology implementation that builds upon modeling. This may encourage a process of teacher educators transferring and communicating knowledge and self-efficacy in technology utilization to students, resulting in best practices for preservice teachers as well as for teacher educators - as portrayed in this study.

Furthermore, professional development was possible due to the technical support provided in the early stages of ICT implementation, which was a major facilitating factor in the 2013 survey. The literature also suggests that in order for change to occur, conditions need to ripen and allow these processes (Ertmer \& Ottenbreit-Leftwich, 2010). This includes the technological aspect, referring to availability and extent of technological equipment, as well as availability and quality of support. In the second survey, two years later, the emphasis on pedagogical aspects as facilitating factors indicates growth of teacher educators and a shift that indicates greater importance of ICTbased practice in schools.

The adaptation of technology to novel pedagogical paradigms requires institutional adaptation as well, as our study reflects. The result suggested by the literature is a joint culture and common language in effective implementation of the expected change (Avalos, 2011; Darling-Hammond, 2000; Hinde, 2004). Also, this requires professional development processes that are tailored for the spirit of change (Borko, 2004). Teachers that feel more competent using technology may cope better with the feeling of challenge in its incorporation in teaching and learning (Krumsvik, 2014); moreover, pedagogical-technological knowledge enables better assessment of the quality of implementation (Thomas et al., 2013).

Managing change is an ongoing endeavor requiring a joint systemic effort of teacher education institutes, in addition to teacher-level factors affecting effective implementation of ICT in preparing future teachers; our data is consistent with this classification (Tondeur et al., 2012). Furthermore, our study shows decrease in the importance of personal factors, e.g., perceptions and beliefs regarding ICT implementation of teacher educators in the second survey. This could be a result of the increase in their experience in using technology for training preservice teachers, as 
well as their growing knowledge in technical issues as a result of ongoing support. These two factors - adequate support and experience in using technology - enable teacher educators to plan their teaching successfully in a way that is beneficial for their preservice students and more focused on their needs as teachers (Scott, 2013).

Hindering factors mentioned in our study were lack of resources, mostly in terms of time, insufficient technological knowledge, skills and competencies, infrastructure deficiencies, and issues regarding institutional policy (e.g., rewarding) - all found in several studies on ICT implementation in education (Black, Smith, \& Lamshed, 2009; Govender, 2012; Surry et al., 2002; Voogt, Knezek, Cox, Knezek, \& ten Brummelhuis, 2013).

Positive beliefs and perceptions of teacher educators towards ICT and its role in education are dynamic, and its importance has increased in the second survey. The finding according to which professional development, e.g., instruction, professional mentoring, and exposure to workshops, were considered more encouraging in the 2013 survey than in the 2015 survey could be a result of empowerment of teacher educators to an extent that enables participants of this study to rely on their developing abilities and self-efficacy; these have been known as fundamental in adoption of innovation and change altogether (Day \& Lindsey, 2009; Fullan, 2001).

What would be considered successful and effective ICT implementation in teacher education may be influenced by the difficulty in defining success. Based on the RIPPLES (Resources, Infrastructure, Policy, People, Learning, Evaluation, Support) model, the tendency to define success in terms of students' techno-pedagogical competencies in utilizing ICT in their practice in the second survey implies that the output must be measured according to direct impact on K12 students in the education system (Surry et al., 2002). Notwithstanding, teacher educators' role is to serve as role models, emphasizing the schools as the target population, e.g., promoting young preservice teachers' self-efficacy and perceived added value of ICT in classroom practices (Lee \& Lee, 2014).

In summary, the success of implementing ICT among teacher educators in their teaching preservice teachers includes external as well as internal factors - both comprising facilitating as well as hindering aspects. Perceptions and beliefs play a major role in ICT implementation in preservice training, as well as technological and pedagogical support in skills and competencies (AvidovUngar, 2016).

\section{Conclusions and Future Research}

Summarizing the findings to the research questions, i.e., factors encouraging or hindering the implementation of ICT among teacher educators in colleges of education and their increase or decrease over the 2 years, our main findings are that technological-pedagogical support encourages ICT implementation as the computerization program advances. However, professional development and rewarding ICT implementation, as well as availability and accessibility of technological equipment and perceptions and beliefs regarding ICT implementation in teaching had decreased. This may possibly be due to the knowledge as well as personal equipment acquired by teacher educators as a new routine. This in turn caused ICT perceptions and beliefs to be a non-issue, i.e., taken for granted as a necessity in teacher training in the information era. Main findings regarding hindering factors were similar in both surveys, i.e., time resources, technological infrastructure and rewarding ICT implementation, and ICT knowledge, skills, and competencies - these still seem to be insufficient. This may indicate the need to consider the new roles of teacher educators in the 21 st century as requiring additional efforts and, as a result, the need for these efforts to be acknowledged somehow.

In the light of the importance of technology as a facilitator of growth in teacher education, the findings of our study are vital in understanding the perceptions, attitudes, and practices of teacher 
educators that involve ICT as a major component. Findings have unveiled the underlying perceptions of teacher educators in colleges of education regarding ICT implementation within the process of preparing future teachers adequately for teaching in the information era.

Since this study was conducted for the first time in Israel with regards to the research questions presented above in colleges of education, it can serve as a basis and a lever for future studies. Fields of studies that may derive from the current study may include the following: (a) Longitudinal examination of initiatives from the teacher, student and organizational level - this may be performed using qualitative research methods; (b) Based on the categories identified in our study - a quantitative survey may be conducted, including additional colleges of education as well as those who participated in the current study; (c) Comparison with international programs for preservice teacher training for innovative use of ICT - this may be performed as a meta-analysis of current programs worldwide; (d) Comparison between facilitating factors, hindering factors and measures of success of ICT implementation between colleges of education and K12 institutes, from the viewpoints of the teacher educators vs. teachers, pre-service teachers vs. students, and stakeholders.

\section{References}

All Aboard - Digital Skills in Higher Education. (2015), Towards a national digital skills framework for Irish higher education: Review and comparison of existing frameworks and models. Retrieved from http://allaboardhe.org/DSFramework2015.pdf

Avidov-Ungar, O. (2016). Understanding teachers' attitude among educational reforms through metaphor. International Journal of Educational Research. 77, 117-127.

Avalos, B. (2011). Teacher professional development in teaching and teacher education over ten years, Teaching and Teacher Education, 27, 10-20.

Buabeng-Andoh, C. (2012). Factors influencing teachers' adoption and integration of information and communication technology into teaching: A review of the literature. International Journal of Education and Development using Information and Communication Technology, 8(1), 136-155.

Borko, H., (2004). Professional development and teacher learning: Mapping the terrain. Educational Researcher Journal, 33(8), 3-15.

Black, G., Smith, K., \& Lamshed, R. (2009). Hot topic: ICT in pre-service teacher training - strategic ICT advisory service. Adelaide, Australia: Australian Government Department of Education, Employment and Workplace Relations. Retrieved Aug. 2016 from http://apo.org.au/files/Resource/ict_in_preservice teacher_training.pdf

Brzycki, D., \& Dudt, K. (2005). Overcoming barriers to technology use in teacher preparation programs. Journal of Technology and Teacher Education, 13(4), 619-641.

Chong, S., Low, E. L., \& Goh, K. C. (2011). Emerging professional teacher identity of pre-service teachers. Australian Journal of Teacher Education, 36(8), 50-64.

Cook, J., Holley, D., \& Andrew, D. (2007). A stakeholder approach to implementing e-learning in a university. British Journal of Educational Technology, 38(5), 784-794.

Cummings, T., \& Worley, C. (2015). Organization development and change. Cengage learning. US: Cengage Learning.

Darling-Hammond, L. (2000). Policy and change: Getting beyond bureaucracy. In A. Hargreaves, A. Liberman, M. Fullen, \& D. Hopkins (Eds.), International handbook of educational change (pp. 642667). Kluwer Academic Publishers.

Darling-Hammond, L. (2006). Constructing $21^{\text {st }}$ - century teacher education. Journal of Teacher Education, 57(3), 300-314. 
Day, C., Elliot, B., \& Kington, A. (2005). Reform, standards and teacher identity: Challenges of sustaining commitment. Teaching and Teacher Education, 21(5), 563-577.

Day, C., \& Lindsey. (2009). The effects of reform: Have teachers really lost their sense of professionalism? Journal of Educational Change, 10(2-3), 141-157.

Drent, M., \& Meelissen, M. (2008). Which factors obstruct or stimulate teacher educators to use ICT innovatively? Computers \& Education, 51(1), 187-199.

Ertmer, P. A., \& Ottenbreit-Leftwich, A. T. (2010). Teacher technology change: How knowledge, confidence, beliefs, and culture intersect. Journal of Research on Technology in Education, 42(3), 255-284.

Finley, L., \& Hartman, D. (2004). Institutional change and resistance: Teacher preparatory faculty and technology integration. Journal of Technology and Teacher Education, 12(3), 319-337.

Fraley, R. C., \& Hudson, N. W. (2014). Review of intensive longitudinal methods: An introduction to diary and experience sampling research. The Journal of Social Psychology, 154(1), 89-91.

Fullan, M. G. (2001). The new meaning of educational change (3rd ed.). New York: Teachers College Press.

Gilster, P. (1997). Digital literacy. John Wiley \& Sons, Inc. Wiley Computer Publications.

Goktas, Y., Yildirim, S., \& Yildirim, Z. (2009). Main barriers and possible enablers of ICTs integration into pre-service teacher education Programs. Educational Technology \& Society, 12(1), 193-204.

Goldstein, O., Waldman, N., Tesler, B., Forkosh-Baruch, A., Shonfeld, M., Mor, N., Heilweil, I., Zelkovitz., Z., Zidan, W., \& Kozminsky, L. (2011). The current state of pre-service teachers training for ICT based teaching in Israel: 2008-2009. Proceedings of Global TIME: Global Conference on Technology, Innovation, Media \& Education (February, 22-24, 2011), AACE.

Goldstein, O., Waldman, N., Tesler, B., Shonfeld, M., Forkosh-Baruch, A., Zelkovitz., Z., Mor, N., Heilweil, I., Kozminsky, L., \& Zidan, W. (2012). Training pre-service teachers for ICT-based teaching and implementation of ICT in colleges of education: state in 2009. Dapim, 54, 20-67. [Hebrew]

Gomez, L. M., Sherin, M. G., Griesdorn, J., \& Finn, L. (2008). Creating social relationships: The role of technology in preservice teacher preparation. Journal of Teacher Education, 59(2), 117-131.

Govender, D. W. (2012). A model to predict educators' attitudes towards technology and thus technology adoption. Africa Education Review, 9(3), 548-568.

Guri-Rosenblit, S. (2002). A top-down strategy to enhance information technologies into Israeli higher education. International Review of Research in Open and Distance Learning, 2(2), 76-91.

Hall, G. E., \& Hord, S. M. (1987). Change in schools: Facilitating the process (pp. 1-22). Albany: SUNY Press.

Hanus, M. D., \& Fox, J. (2015). Assessing the effects of gamification in the classroom: A longitudinal study on intrinsic motivation, social comparison, satisfaction, effort, and academic performance. Computers \& Education, 80, 152-161.

Harari, H. (Ed.). (1992). Report of the Highest Committee for Science and Technology Education "Tomorrow 98". Jerusalem: MOE. [Hebrew]

Hardy, I. (2010). Critiquing teacher professional development: Teacher learning within the field of teachers' work. Critical Studies in Education, 51(1), 71-84.

Hinde, E. R. (2004). School culture and change: An examination of the effects of school culture on the process of change. Essays in Education, 12, 1-12.

Hultman, K. (1995). Scaling the wall of resistance. Training .Development, 49(10), 15-18.

Kaniuka, T. S., (2012). Toward an understanding of how teachers change during school reform: Considerations for educational leadership and school improvement. Journal of Educational Change. 13(3), 327346. 
Kay, R. H. (2006). Evaluating strategies used to incorporate technology into preservice education: A review of the literature. Journal of Research on Technology in Education, 38(4), 383-408.

Kelly, A. E., Lesh, R. A., \& Baek, J. Y. (2014). Handbook of design research methods in education: Innovations in science, technology, engineering, and mathematics learning and teaching. Routledge.

Koster, B., Brekelmans, M., Korthagen, F., \& Wubbels, T. (2005). Quality requirements for teacher educators. Teaching and Teacher Education, 21, 157-176.

Kotter, J. P., \& Cohen, D. S. (2012). The heart of change: Real-life stories of how people change their organizations. Boston: Harvard Business Press.

Krumsvik, R. J. (2014). Teacher educators' digital competence. Scandinavian Journal of Educational Research, 58(3), 269-280.

Lamote, C., \& Engels, N. (2010). The development of student teachers' professional identity. European Journal of Teacher Education, 33(1), 3-18.

Lee, Y., \& Lee, J. (2014). Enhancing pre-service teachers' self-efficacy beliefs for technology integration through lesson planning practice. Computers \& Education, 73, 121-128.

Lewin, K. (1951). Field theory in social science: Selected theoretical papers. New York: Harper.

Lim, C. P., Chai, C. S., \& Churchill, D. (2011). A framework for developing pre-service teachers' competencies in using technologies to enhance teaching and learning. Educational Media International, 48(2), 69-83.

Liu, S. H. (2011). Factors related to pedagogical beliefs of teachers and technology integration. Computers \& Education, 56(4), 1012-1022.

Loughran, J. (2014). Professionally developing as a teacher educator. Journal of Teacher Education, 65(4), 271-283.

Mandinach, B. E. (2005). The development of effective evaluation methods for e-learning: A concept paper and action plan. Teachers' College Record, 107(8), 1814-1835.

Martin, B. (2015). Successful implementation of TPACK in teacher preparation programs. International Journal on Integrating Technology in Education, 4(1), 17-26.

Mckeon, F., \& Harrison, J. (2011). Developing pedagogical practices and professional identities of beginning teacher educators. In T. Bates, A. Swennen, \& K. Jones (Eds.), The professional development of teacher educators. London: Routledge.

Merseth, K. K., Sommer, J., \& Dickstein, S. (2008). Bridging worlds: Changes in personal and professional identities of pre-service urban teachers. Teacher Education Quarterly, 35(3), 89-108.

Ministry of Education. (2003). The program for computerization of the education system: stage 3. Israel: MOE.

Ministry of Education. (2011). The Adaptation of the Education System to the 21st century-A masterplan. Jerusalem: MOE.

Ministry of Education. (2012). Regulations of the department for teacher training: preparation for deployment of the plan for adapting education colleges to education in the 21 st century. Israel: MOE. [Hebrew]. Retrieved Dec. 2013 from

http://cms.education.gov.il/EducationCMS/Units/HachsharatOvdeyHoraa/Hozrim/HearchutMumanuyo $\underline{\mathrm{t} 21 . \mathrm{htm}}$

Ministry of Education. (2015). The Academia Kita Program. Retrieved October 2016 from http://academiakita.macam.ac.il/eng/Pages/default.aspx

Mioduser, D., Nachmias, R., \& Forkosh-Baruch, A. (2008). New literacies for the knowledge society. In J. Knezek \& J.Voogt (Eds.), International handbook of information technology in education (pp. 23-42). NY: Springer. 
Mumtaz, S. (2000). Factors affecting teachers' use of information and communications technology: A review of the literature. Journal of Information Technology for Teacher Education, 9(3), 319-341.

Plomp, T., Anderson, R.E., Law, N., \& Quale, A. (Eds). (2009). Cross-national information and communication technology policy and practices in education (2nd ed.). US: Information Age Publishing Inc.

Pope, M., Hare, D., \& Howard, E. (2005). Enhancing technology use in student teaching: A case study. Journal of Technology and Teacher Education, 13(4), 573-618.

Rimon, O. (2010). Adaptation of the education system to the 21st century: The new plan of the Ministry of Education. Hed Hachinuch, 12, 40-45. [Hebrew] Retrieved Dec. 2013 from http://cms.education.gov.il/NR/rdonlyres/62E534AB-E474-4C60-B03AFC02440B33B4/125568/Hinucdigitali.pdf

Rogers, E. M. (1995). Diffusion of innovations (4th ed.). New York: The Free Press.

Scherer, R., Siddiq, F., \& Teo, T. (2015). Becoming more specific: Measuring and modeling teachers' perceived usefulness of ICT in the context of teaching and learning. Computers \& Education, 88, 202214.

Scott, W. R. (2013). Institutions and organizations: Ideas, interests, and identities. US: Sage Publications.

Siemens, G., \& Tittenberger, P. (2009). Handbook of emerging technologies for learning. Manitoba, Canada: University of Manitoba.

Sung, T.K., \& Gibson, D.V. (2015). Knowledge and technology transfer: levels and key factors. International Conference on Technology Policy and Innovation (ICTPI). UK: Milton Keynes.

Surry, D. W., Ensminger, D. C., \& Haab, M. (2005). A model for integrating instructional technology into higher education. British Journal of Educational Technology, 36(2) 327-329.

Surry, D. W., Ensminger, D. C., \& Jones, M. (2002). A model for integrating instructional technology into higher education. Paper presented at the annual meeting of the American Educational Research Association, New Orleans, LA.

Teclehaimanot, B., Mentzer, G., \& Hickman, T. (2011). A mixed methods comparison of teacher education faculty perceptions of the integration of technology into their courses and student feedback on technology proficiency. Journal of Technology and Teacher Education, 19(1), 5-21.

Teo, T. (2010). A path analysis of pre-service teachers' attitudes to computer use: applying and extending the technology acceptance model in an educational context. Interactive Learning Environments, 18(1), 65-79.

Teo, T. (2011). Factors influencing teachers' intention to use technology: Model development and test. Computers \& Education, 57(4), 2432-2440.

Thomas, T., Herring, M., Redmond, P., \& Smaldino, S. (2013). Leading change and innovation in teacher preparation: A blueprint for developing TPACK ready teacher candidates. TechTrends, 57(5), 55-63.

Toledo, C. (2005). A five-stage model of computer technology integration into teacher education curriculum. Contemporary Issues in Technology and Teacher Education, 5(2), 177-191.

Tondeur, J., van Braak, J., Sang, G., Voogt, J., Fisser, P., \& Ottenbreit-Leftwich, A. (2012). Preparing preservice teachers to integrate technology in education: A synthesis of qualitative evidence. Computers \& Education, 59(1), 134-144.

UNESCO, (2009). Guide to measuring information and communication technology (ICT) in education. Paris: United Educational, Scientific and Cultural Organization. Retrieved December 22, 2013 from: http://www.uis.unsco.org/temlate/pdf/cscl/ICT/ICT_Guide_EN.pdf.

Voogt, J., Knezek, G., Cox, M., Knezek, D., \& ten Brummelhuis, A. (2013). Under which conditions does ICT have a positive effect on teaching and learning? A call to action. Journal of Computer Assisted Learning, 29(1), 4-14. 


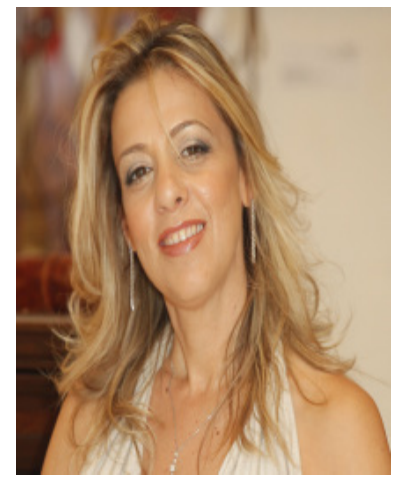

\section{Biographies}

Dr. Orit Avidov-Ungar is the Head of Research Authority and senior lecturer at the School of Education Systems Management at Achva Academic College she is also a member of the faculty of the Open University in Israel. She heads the specialization in professional development at the Mofet Institute and is the academic advisor to the Ministry of Education in Israel management in the implementation of innovative technology systems and the professional development of teachers. Her research studies deal with the implementation of innovative technologies in education systems, the empowerment and professional development of teachers, and leading organizational change in education systems.

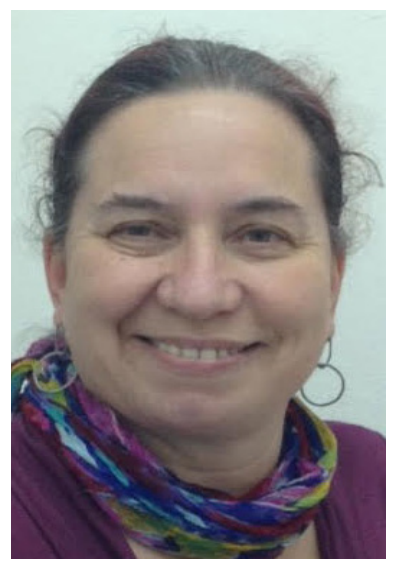

Alona Forkosh-Baruch is a senior lecturer at the Graduate school at Levinsky College of Education and a researcher at the Science and Technology Education Center in the School of Education, Tel Aviv University (Israel). She holds a Ph.D. in Science Education, an M.A. in Technologies in Education and a B.A in Psychology and in Education. Her research interest intersects several aspects of Information and Communication Technologies in education, from teachers', students', pre-service teachers' and teacher educators' point of view. Among her fields of research are: mobile technology in education and teacher education, social media in education and education in the social media era, teacher professional development and systemic implementation of technology in education. Her research studies deal with the implementation of innovative technologies in education systems, the empowerment and professional development of teachers, and leading organizational change in education systems. 